\title{
Perceived workload and organizational citizenship behavior (OCB): The role of psychological empowerment
}

\author{
Fef Rama Jaya Wijaya, ${ }^{1}$ Debora Eflina Purba ${ }^{1 *}$ \\ ${ }^{1}$ Faculty of Psychology, Universitas Indonesia, Depok - Indonesia
}

\begin{abstract}
Organizational Citizenship Behavior (OCB) refers to employee behavior that is voluntary and does not attract formal rewards from organizations, but which can increase their effectiveness and efficiency. This study aims to examine the mediating effect of psychological empowerment on the relationship between perceived workload and OCB. Data were collected using the snowball sampling method and an online survey of 201 employees aged 19-50 working in various private organizations in Indonesia, particularly in the Jakarta, Indonesia (female: 54.7\%; male: $45.7 \%$ ). The measuring instruments used were the workload subscale of the Job Demand-Resource scale, the Psychological Empowerment Questionnaire (PEQ), and the OCB subscale of the Task Performance Scale. Data were analyzed by the mediation technique using Hayes's Macro. The results show that perceived workload positively predicted psychological empowerment $(B=0.192, p<.01)$ and that psychological empowerment positively predicted OCB $(B=0.2189, p<.01)$. The results also show that psychological empowerment mediated the relationship between perceived workload and OCB $(B=0.021, S E=0.0160,95 \%$ CI $[0.0143$, $0.0759]$ ). From the findings, it is expected that organizations will be able to manage the workload of their employees and create positive emotions in it.
\end{abstract}

Keywords: approach-avoidance theory; organizational citizenship behavior; psychological empowerment; perceived workload

\begin{abstract}
Abstrak: Organizational Citizenship Behavior (OCB) adalah perilaku karyawan yang bersifat sukarela dan tidak mendapatkan reward secara formal dari organisasi jika ditampilkan, tetapi secara agregat dapat meningkatkan efektivitas dan efisiensi organisasi. Penelitian ini bertujuan untuk melihat efek mediasi pemberdayaan psikologis pada hubungan antara persepsi beban kerja dan OCB. Data diambil dengan metode snowball sampling menggunakan survei daring pada 201 karyawan usia 1950 tahun dari berbagai organisasi swasta di Indonesia, khususnya wilayah Jakarta (perempuan: 54,7\%; laki-laki: 45,7\%). Alat ukur yang digunakan dalam penelitian ini adalah subskala beban kerja dari skala Job Demand-Resource, Psychological Empowerment Questionnaire (PEQ), dan subskala OCB dari Task Performance Scale. Data dianalisis menggunakan teknik mediasi menggunakan Hayes's Macro. Hasil penelitian menunjukkan bahwa persepsi beban kerja memprediksi pemberdayaan psikologis secara positif $(B=0,192, p<0,01)$ dan pemberdayaan psikologis memprediksi OCB secara positif $(B=0,2189, p<0,01)$. Hasil penelitian juga menunjukkan pemberdayaan psikologis memediasi hubungan antara persepsi beban kerja dan OCB $(B=0,021, S E=0,0160,95 \%$ CI $[0,0143,0,0759])$. Dari temuan ini diharapkan organisasi dapat mengelola beban kerja karyawan menjadi emosi positif di dalamnya.
\end{abstract}

Kata Kunci: approach-avoidance theory; perilaku kewargaan organisasi; pemberdayaan psikologis; persepsi beban kerja

\footnotetext{
*Corresponding Author: Debora Elfina Purba (e-mail: eflina@ui.ac.id). Faculty of Psychology, Universitas Indonesia. Kampus Baru UI Depok, Depok 16424-Indonesia.
} 


\section{Introduction}

In today's competitive environment, every organization must keep trying to achieve excellence by increasing their effectiveness and efficiency. One of the ways for an organization to achieve effectiveness and efficiency is by having employees with high performance. Employee performance in organization can be categorized into mandatory performance (in-role performance) and extra-role performance, which is commonly known as Organizational Citizenship Behavior (OCB) (Dash \& Pradhan, 2014). This study focused on OCB because OCB is considered as the quality of employees that can distinguish the performance of one organization from the others (Organ, 2009). OCB is defined as an individual's behavior that is not displayed in job description, is constructive and is not assessed or rewarded by other parties if displayed (Organ, 2009). It does not have a direct correlation with an individual's productivity or work rewards obtained from the organization, but if done, in the aggregate it will improve organizational performance.

The most important thing that distinguishes OCB from the other forms of behavior in the organization is the absence of rewards for employees because it is exhibited on a voluntary basis without the expectations to be rewarded both from other employees and the organization when they help the co-workers or the organization (Baron \& Byrne, 1987; Organ, 2009). Some examples of OCB given to individuals are helping co-workers who are absent from work, helping new employees adapt to the working environment, and assisting superiors in arranging work schedules without being asked. Some examples of OCB in the organization are refraining from taking longer breaks than necessary, maintaining cleanliness in the workplace, and sharing positive things about the organization with outsiders.

Until now the interest in research related to OCB is still quite large. Since the idea was first proposed by Organ in 1988 until today, more than 40,000 articles are accessible on Google Scholar sites related to the issue of OCB. Most studies focusing on the effects of OCB discovered that OCB has positive effects on individuals, such as assessing employees' performance (Allen \& Rush, 1998; Turnipseed \& Rassuli, 2005), on group, such as improving team performance (Nielsen, Bachrach, Sundstrom, \& Halfhill, 2012), as well as on organization, such as improving organizational performance (Podsakoff, Whiting, Podsakoff, \& Blume, 2009). Thus, OCB is an important variable and remains relevant today.

Previous studies have found factors of OCB, which can be categorized as internal factors and external factors. The internal factors of OCB include gender, age, marital status, personality (Emami, Alizadeh, Nazari, \& Darvishi, 2012), worker's motivation (Sulea et al., 2012), interest and prosocial motives (Michel, 2017). The external factors include workplace atmosphere (Suresh \& Venkatammal, 2010), organizational commitment, organizational justice (Emami et al., 2012), role stressors (Eatough, Chang, Miloslavic, \& Johnson, 2011), work engagement (Sulea et al., 2012), role overload, and interpersonal conflict (Pooja, De Clercq, \& Belausteguigoitia, 2016). Based on the study conducted by Eatough et al. (2011) role stressors are role ambiguity, role conflict, and role overload. Role ambiguity refers to the unclear organization's expectations regarding the roles each employee must carry out, which make them feel confused about what to do. Role conflict is some conflicting roles given by an organization that makes it hard for 
employees to complete their tasks (Katz \& Kahn, 1978). Meanwhile, role overload refers to employees' perception of the extent of responsibility that they must carry out in a relatively short time and with a high concentration in connection with their work (Rizzo, House, \& Lirtzman, 1970). This study focused on role overload (workload) as the factor that affects OCB, considering that the era of globalization increases the complexity of employees' works in an organization, which can negatively affect their attitudes and behavior. Role overload refers to the physical, social, or organizational aspects of work that require physical and mental efforts and is associated with certain physical and psychological burdens (Demerouti, Bakker, Nachreiner, \& Schaufeli, 2001). Role overload in an organization includes demands for faster and harder work, the number of works that must be done in a short time, and high workload that requires high concentration (Janssen, 2000).

Several previous studies have revealed a negative correlation between workload and OCB (Eatough et al., 2011; Pooja et al., 2016). Eatough et al. (2011) in their meta-analysis, analyzed 1924 studies that focused on the relationship between types of work demands (such as role ambiguity, role conflict, and workloads) and OCB, and discovered that out of the three work demands, role ambiguity and role conflicts were found to have consistent negative correlation with OCB. On the other hand, workload is found not to be significantly correlated with OCB.

According to Eatough et al. (2011), there are two possible responses of individuals in coping with high workloads based on the theory of approach and avoidance motivation (Carver \& White, 1994). First, according to the avoidance motivation theory, individuals with high work- loads can experience negative effects, thereby reducing their performance, including cooperative behavior and helping co-workers, because they feel that their workloads are too high. In this case, high workloads negatively affect OCB because individuals feel they do not have the resources to help others. Second, according to the theory of approach motivation, individuals become motivated to complete their work and show positive organization behaviors because they consider the work as challenging. High workloads can be interpreted as an increase in responsibility and work challenges that require cooperation with other employees to solve it. By displaying OCB, individuals expect that coworkers would return their favor when needed in the future. In this case, high workloads can have a positive effect on OCB.

Crawford, LePine, and Rich (2010) in their meta-analysis of job demand and work engagement found that work demand has a positive effect on work engagement. Based on the theory of approach motivation, we consider that although employees perceive that their workloads are high, they are still able to show OCB. This argument is supported by the characteristics of Indonesian employees who have high collectivistic values (Hofstede \& Hofstede, 2005), in which social care is the adopted norm. For individuals who come from collectivistic culture, helping others who need help is mandatory even if the individual has a high workload (Moorman \& Blakely, 1995).

However, previous studies showed the relationship between workload and OCB is relatively small or insignificant (see the metaanalysis of Eatough et al., 2011). It indicates that there is a psychological mechanism that connects the perception of workload and OCB. We 
assumed that psychological empowerment is an individual factor that can mediate the correlation between perception of workload and OCB. Psychological empowerment is defined as a psychological condition manifested in four dimensions, namely 1) meaningfulness, which means how meaningful an individual perceives his/her work, 2) competence, which means the level of individual's confidence about their ability to perform their jobs well, 3) self-determination, which means the ability of an individual to control, initiate, and regulate their actions at work, and 4) the impact on work (impact), which means the ability of an individual to influence the results of their work (Spreitzer, 1995). Psychological empowerment has been perceived as a personal quality that gives an individual power to make decisions (Randolph, 1995).

This variable is unique because previous studies have found that psychological empowerment is a mediating variable in OCB research (Joo \& Jo, 2017). Other studies have found that psychological empowerment acts as a moderator in the correlation of other variables with OCB (Jha, 2014). Finally, research from Chiang and Hsieh (2012), found that psychological empowerment has a direct effect on OCB. The results of the studies above indicate that the correlation between psychological empowerment and OCB is relatively proximal.

In general, previous studies have found that the correlation between psychological empowerment and OCB is positive (Chiang \& Hsieh, 2012; Jha, 2014; Joo \& Jo, 2017; Taylor, 2013). It occurs because the four dimensions of psychological empowerment are self-identified by individuals based on their interests (Schlechter \& Engelbrecht, 2006). High psychological empowerment enables individuals to create a conducive, innovative, and supportive work environment (Alge, Ballinger, Tangirala, \& Oakley, 2006). In other words, if employees feel that their work is meaningful and has a positive impact, they will make more efforts to improve the quality of their work. Individuals who have high psychological empowerment are more innovative and creative, confident about their ability to complete work and perform OCB (Spreitzer, 1995). Empowerment means the participation of individuals that is voluntary, not limited to the tasks assigned to them. Therefore, individuals who have high psychological empowerment are expected to display OCB behavior. The following hypothesis is based on the above explanations:

Hypothesis 1: Psychological empowerment has a positive effect on $O C B$.

Studies that link role stressors, especially workload, to psychological empowerment are still scarce. A meta-analysis conducted by Seibert, Wang, and Courtright (2011) found that job characteristics, including challenges at the workplace, have positive correlation with psychological empowerment. Taylor (2013) also found that work demands, such as difficult workloads, have a positive effect on psychological empowerment because a high workload provides psychological satisfaction to employees when they can handle it properly. Therefore, it increases a sense of psychological empowerment. In addition, delegation of high workload is often associated with high trust from the organization to employees because they are considered capable of doing the work. This leads to the second hypothesis.

Hypothesis 2: Workload has a positive effect on psychological empowerment. 
Based on the above arguments, we assumed that psychological empowerment can act as a mediator in the relationship between workload and OCB. We used the positive organizational behavior (POB) theoretical framework Bakker (2008) to explain the relationship between the three variables. The POB theoretical framework emphasizes the ability of human resource practices and the capacity of individuals to improve organization's performance. In the POB framework, human resource practices, including those contributing to role stressors to individuals, can positively increase employees' capacity so that they are able to show the attitudes and sets of behavior expected by the organization. Employees' perceptions of workloads, in the framework of $\mathrm{POB}$, increase their psychological empowerment, competence, independence, and job impact because high workloads are perceived as challenging rather than obstructing. High psychological empowerment can in turn increase OCB behavior (Chiang \& Hsieh, 2012; Jha, 2014; Joo \& Jo, 2017; Taylor, 2013). Therefore, we propose the third hypothesis below.

Hypothesis 3: Psychological empowerment acts as mediator in the correlation between workload and OCB.

\section{Method}

The participants of this study came from various private organizations in Jakarta and the surrounding areas. We sent a message in a whatsapp group, asking the willingness of other group members who were employees of private organizations to participate in the study. These private organizations were chosen as the research contexts because workloads in private companies are relatively higher compared to those in governmental organizations. We also requested the participants' willingness to share the survey link with their co-workers. Through the snowball sampling method, we expected to obtain a larger number of samples. The online survey page was opened during March 2019. At the end of the month, 202 participants filled the survey. We excluded 1 participant because the person did not provide complete demographic data, so the number of samples analyzed was 201. Most of them were women (54.7\%). Their ages ranged from 19 to $50(\mathrm{M}=30.71, \mathrm{SD}=7.64)$. The number of participants with the last education of high school-non-degree diploma was 31 people (15.4\%), bachelor degree was 101 (50.2\%), master degree was 68 (33.8\%), and doctoral degree was $1(0.5 \%)$. There were $23(11.4 \%)$ people serving as managers, 27 (13.4\%) people as supervisors, and 151 (75.1\%) people as staff.

\section{Scales}

Workload. The workload was measured using job demand-resource scale developed by Karasek (1979). This measuring instrument was adapted into Indonesian by Nurhanni (2016). It consists of 9 items using a Likert Scale with the answer range of 1-6 (1 = Strongly Disagree, $6=$ Strongly Agree). One example of the items that measure workload is "My workload is too much". The coefficient $\alpha$ for this questionnaire is 846 .

Organizational Citizenship Behavior (OCB). OCB measurement used the Task Performance Scale developed by Williams and Anderson (1991), which consists of 14 items. This measuring instrument was adapted into Indonesian by Purba and Muhammad (2020). It uses a Likert Scale with the answer range of 1 - 5 ( 1 = Strongly Disagree, 5 = Strongly Agree). One example of the items is "I help my boss' work without being asked". The coefficient $\alpha$ for this questionnaire is .739. 
Psychological empowerment. This variable was measured using a Psychological Empowerment Questionnaire (PEQ), which was developed by Spreitzer (1995). This measuring instrument was adapted into Indonesian by Armelia (2012). This instrument consists of 12 items. It uses a Likert Scale with the answer range of 1-6 (1 = Strongly Disagree, $6=$ Strongly Agree). One example of the items is "I have a big impact on my work unit". The coefficient $\alpha$ for this questionnaire is .820 .

\section{Data Analysis}

The data were analyzed using SPSS v.23, specifically the mediation analysis technique using PROCESS Macro Hayes model 4 (simple mediation model).

\section{Results}

Table 1 shows the correlation among the variables. Workload had a positive correlation with OCB $(\mathrm{r}=.14, \mathrm{p}<.05)$. This means that employees who have high work demands tend to exhibit high level of OCBs. Workload had a positive correlation with psychological empowerment $(\mathrm{r}=.28, \mathrm{p}<.01)$. This result means that employees who have high workloads tend to have high psychological empowerment.
Psychological empowerment had a positive correlation with OCB $(r=.30, \mathrm{p}<.01)$. This means that employees who have high psychological empowerment tend to exhibit high OCB behavior.

Table 2 shows the results of regression with mediation analysis technique using the PROCESS macro in the SPSS program (Preacher \& Hayes, 2008). The hypothesis 1 which stated that psychological empowerment has a positive effect on OCB was supported by the data $(b=0.2189$, $\mathrm{SE}=0.0571, \mathrm{p}=.0002,95 \% \mathrm{CI}[0.1063,0.3315])$. The results showed that workload had a positive effect on psychological empowerment $(b=0.192$, $\mathrm{SE}=0.047, \mathrm{p}=.0001,95 \%$, CI $[0.0999,0.2852])$. Thus, the hypothesis 2 which stated that workload has a positive effect on psychological empowerment was supported by the data. Thus, the results showed that the indirect effect of workload on OCB through psychological empowerment was significant (Indirect effect $=$ 0.021, Boot $\mathrm{SE}=0.0160,95 \% \mathrm{CI}[0.0143$, 0.0759]). These results indicated that the hypothesis 3 which stated that psychological empowerment acts as a mediator in the correlation between workload and OCB was supported by the data.

Table 1

Mean, Deviation Standard, and Correlation among the Variables

\begin{tabular}{lllllllll}
\hline & $\mathrm{M}$ & $\mathrm{SD}$ & 1 & 2 & 3 & 4 & 5 & 6 \\
\hline 1. Age & 30.74 & 7.64 & 1 & & & & & \\
2. Gender & - & - & -0.2 & 1 & & & & \\
3. Last Education & 3.05 & .97 & .00 & $.15^{*}$ & 1 & & & \\
4. Psychological Empowerment & 4.92 & 0.57 & $.21^{* *}$ & -.08 & -.01 & 1 & & \\
5. Workload & 4.41 & 0.81 & .05 & .08 & .02 & $.28^{* *}$ & 1 \\
6. Organizational Citizenship Behavior & 4.12 & 0.45 & .120 & -.07 & $.15^{*}$ & $.30^{* *}$ & $.14^{*}$ & 1 \\
\hline
\end{tabular}

Note. $\mathrm{N}=201$; age measured in year; education code $(1=$ high school, $2=$ non-degree diploma, $3=$ bachelor's degree, 4 = master's degree, $5=$ doctoral degree); ${ }^{*} \mathrm{p}<.05{ }^{* *} \mathrm{p}<.01$. NA = not applicable 
Table 2

The effect of Psychological Empowerment's Mediation on Workload-OCB

\begin{tabular}{|c|c|c|c|c|c|c|c|c|}
\hline \multirow{3}{*}{ Antecedents } & \multicolumn{8}{|c|}{ Outcomes } \\
\hline & \multicolumn{4}{|c|}{ M (Psychological Empowerment) } & \multicolumn{4}{|c|}{$\mathrm{Y}(\mathrm{OCB})$} \\
\hline & & $\mathrm{b}$ & SE & $p$ & & $\mathrm{~b}$ & SE & $\mathrm{p}$ \\
\hline \multirow{2}{*}{ Workload } & \multirow{2}{*}{$\alpha$} & \multirow{2}{*}{0.192} & \multirow{2}{*}{0.047} & \multirow{2}{*}{$<.001$} & $c$ & 0.077 & 0.039 & .049 \\
\hline & & & & & $c^{\prime}$ & 0.035 & 0.039 & .374 \\
\hline $\begin{array}{l}\text { Psychological } \\
\text { empowerment }\end{array}$ & & - & - & - & $b$ & 0.219 & 0.057 & .000 \\
\hline Constant & $i_{1}$ & \multicolumn{3}{|c|}{$\begin{array}{l}\mathrm{R}^{2}=.118 \\
\mathrm{~F}(3,197)=8.780 ; \mathrm{p}=.000\end{array}$} & $i_{2}$ & \multicolumn{3}{|c|}{$\begin{array}{l}\mathrm{R}^{2}=.121 \\
\mathrm{~F}(4196)=6763 \cdot \mathrm{n}=000\end{array}$} \\
\hline
\end{tabular}

Note. Indirect effect $=0.0421$, Boot SE $=0.0160,95 \%$ CI $[0.0143,0.0759]$

\section{Discussion}

The main objective of this study was to investigate the effect of psychological empowerment on the correlation between workload and OCB. The discussion of the results of this study was arranged based on the research hypotheses. This study discovered a positive correlation between psychological empowerment and OCB. This result supported previous studies (Chiang \& Hsieh, 2012; Jha, 2014; Joo \& Jo, 2017; Taylor, 2013), indicating that individuals with high psychological empowerment are more creative, innovative, confident, and independent. Thus, they are willing and happy to perform some works that are not written in their job descriptions, such as helping their colleagues and organizations.

Therefore, this study revealed a positive and significant correlation between workload and psychological empowerment. This result supported previous studies by Seibert et al. (2011) and Taylor (2013). This can happen because employees who have high workloads will feel an increase in the significance of work, a high level of confidence in the completion of their work, able to control their works, and that the results of their works have significant impacts on the organization.

Finally, this study showed that psychological empowerment fully mediates the relationship between workload and OCB. The results indicated that employees who have high workloads feel an increase in psychological empowerment because they turn perceptions of workloads into work challenges so as to create a feeling that their work is meaningful, that their levels of confidence and ability to regulate actions increase, and that they have important impacts on others. When psychological empowerment increases, employees are able to display discretionary behavior that is not listed in their job descriptions, namely OCB behavior. This result is in line with the POB thinking framework (Bakker et al., 2008).

To the best of our knowledge, this study was among the first studies that found the role of psychological empowerment as a mediator in the correlation between workload and OCB.

Another contribution of this study is the finding of a positive and significant correlation 
between workload and OCB. This result points out that employees who have high workloads tend to perform high level of helpful behaviors to co-workers and organizations as well. The results of research on the positive effect of workload and OCB are different compared to those of previous studies (Eatough et al., 2011; Pooja et al., 2016). Eatough et al. (2011) who conducted a metaanalysis of more than 20 studies of work demands and OCB concluded that workload does not correlate significantly with OCB. However, the results of this study are in line with the metaanalysis conducted by Crawford et al. (2010), who found that workload positively influences positive behavior in organizations such as work engagement. OCB, like work engagement, is an example of positive behavior in an organization.

This result can be explained by the theory of approach and avoidance motivation (Carver \& White, 1994), specifically the approach motivation. Based on this theory, employees perceive high workload as a challenge, so they can still display discretionary behavior such as helping co-workers who are absent, not complaining about problems that arise at work, and helping new employees adjust themselves in the workplace. The nature of the societies from where the subjects of this study came from was collective, which means that they are more concerned with group interests over individual interests. That is why workload is positively related to OCB. Indonesian people's collective culture (Hofstede \& Hofstede, 2005) makes it easier for the people to keep helping co-workers even though they have high workloads. They consider the organization as a second home. To prove the effect of this cultural difference, further study is expected to replicate the model of this study by involving subjects from societies that are more individualistic in order to see whether the same model of study can be generalized in different cultures.

Another reason is that the level of employees' trust in management was found to moderate the correlation between workload and work stress (Harvey, Kelloway, \& Duncan-Leiper, 2003). Based on this result, it is possible that high workload does not prevent employees from displaying OCB because they trust the management or organization. There is a general assumption that applies in organizations, that employees who have a higher workload are usually the ones who get higher trust from the supervisor. Such Supervisor's trust makes the subordinate respond by displaying OCB behavior. As far as we know, this assumption has never been proven through empirical studies, especially those done in collective societies, so we suggest further study to prove the assumption.

This study focused on one of work demands only as a predictor of OCB, namely workload. Future studies can focus on other types of work demands, namely role ambiguity and role conflict, as predictors of OCB. Eatough et al. (2011) found that role ambiguity and role conflict are negatively correlated with to OCB in the results of different studies. Future studies can also measure perception of workload in employees longitudinally to see whether there is a nonlinear correlation between workload and OCB over time.

Practically, the results of this study can be used by organizations to review their employees' workloads. This study proved that workload has positive correlation with positive attitudes and behaviors of employees because they are able to perceive their workloads as work challenges. Thus, organizations can manage their employees' 
workloads in such a way that they are able to see opportunities in their workloads so as to generate positive emotions in them (Crawford et al., 2010). Challenging workloads for employees can also increase their psychological empowerment so that they are able to display OCB behavior.

\section{Conclusion}

This study discovered that psychological empowerment plays a role as the mediator of positive correlation between workload and OCB, contributing to literature concerning this subject matter. However, there were limitations to this study. First, we used cross-sectional design, in which the measuring of all variables is conducted in one period of time. So, it is recommended to use longitudinal design in the future studies because workload, psychological empowerment, and OCB behavior may likely change over time. In addition, high workload in a long time can also have a negative effect on the attitude and working behavior of an employee. Second, all the variables were measured through self-report method, which can increase the potential of common method bias (MacKenzie \& Podsakoff, 2012).

In line with the suggestion of MacKenzie and Podsakoff (2012), we recommend using temporal separation for collecting data, in which the predictor, mediator, and outcome are taken in different period of time. Additionally, we recommend the use of different rating methods to measure OCB, for example, using superiors or co-workers.]

\section{References}

Alge, B. J., Ballinger, G. A., Tangirala, S., \& Oakley, J. L. (2006). Information privacy in organizations: Empowering creative and extrarole performance. Journal of Applied Psychology, 91(1), 221232. https://doi.org/10.1037/0021-9010.91.1.221

Allen, T. D., \& Rush, M. C. (1998). The effects of organizational citizenship behavior on performance judgments: A field study and a laboratory experiment. Journal of Applied Psychology, 83(2), 247-260. https://doi.org/10.1037/0021-9010.83.2.247

Armelia, R., \& Sjabadhyni, B. (2012). Hubungan antara psychological capital dan psychological empowerment pada perawat. Universitas Indonesia.

Bakker, A. B., Schaufeli, W. B., Leiter, M. P., \& Taris, T. W. (2008). Work engagement: An emerging concept in occupational health psychology. Work \& Stress, 22(3), 187-200. https://doi.org/10.1080/02678370802393649

Baron, R. A., \& Byrne, D. (1987). Social psychology: Understanding human interaction. Allyn \& Bacon.

Carver, C. S., \& White, T. L. (1994). Behavioral inhibition, behavioral activation, and affective responses to impending reward and punishment: The BIS/BAS Scales. Journal of Personality and Social Psychology, 67(2), 319-333. https://doi.org/10.1037/0022-3514.67.2.319

Chiang, C.-F., \& Hsieh, T.-S. (2012). The impacts of perceived organizational support and psychological empowerment on job performance: The mediating effects of organizational citizenship behavior. International Journal of Hospitality Management, 31(1), 180-190. https://doi.org/10.1016/j.ijhm.2011.04.011 
Crawford, E. R., LePine, J. A., \& Rich, B. L. (2010). Linking job demands and resources to employee engagement and burnout: A theoretical extension and meta-analytic test. Journal of Applied Psychology, 95(5), 834-848. https://doi.org/10.1037/a0019364

Dash, S., \& Pradhan, R. K. (2014). Determinants \& consequences of organizational citizenship behavior: A theoretical framework for Indian manufacturing organisations. International Journal of Business and Management Invention, 3(1), 17-27.

Demerouti, E., Bakker, A. B., Nachreiner, F., \& Schaufeli, W. B. (2001). The job demands-resources model of burnout. Journal of Applied Psychology, 86(3), 499-512. https://doi.org/10.1037/00219010.86.3.499

Eatough, E. M., Chang, C.-H., Miloslavic, S. A., \& Johnson, R. E. (2011). Relationships of role stressors with organizational citizenship behavior: A meta-analysis. Journal of Applied Psychology, 96(3), 619632. https://doi.org/10.1037/a0021887

Emami, M., Alizadeh, Z., Nazari, K., \& Darvishi, S. (2012). Antecedents and consequences of organisational citizenship behaviour (OCB). Interdisciplinary Journal of Contemporary Research in Business, 3(9), 494-505.

Harvey, S., Kelloway, E. K., \& Duncan-Leiper, L. (2003). Trust in management as a buffer of the relationships between overload and strain. Journal of Occupational Health Psychology, 8(4), 306-315. https://doi.org/10.1037/1076-8998.8.4.306

Hofstede, G., \& Hofstede, G. J. (2005). Cultures and organizations: Software of the mind (2nd ed.). McGraw Hill.

Janssen, 0. (2000). Job demands, perceptions of effort-reward fairness and innovative work behaviour. Journal of Occupational and Organizational Psychology, 73(3), 287-302. https://doi.org/10.1348/096317900167038

Jha, S. (2014). Transformational leadership and psychological empowerment: Determinants of organizational citizenship behavior. South Asian Journal of Global Business Research, 3(1), 1835. https://doi.org/10.1108/SAJGBR-04-2012-0036

Joo, B.-K., \& Jo, S. J. (2017). The effects of perceived authentic leadership and core self-evaluations on organizational citizenship behavior: The role of psychological empowerment as a partial mediator. Leadership \& Organization Development Journal, 38(3), 463-481. https://doi.org/10.1108/LODJ-11-2015-0254

Karasek, R. A. (1979). Job demands, job decision latitude, and mental strain: Implications for job redesign. Administrative Science Quarterly, 24(2), 285-308. https://doi.org/10.2307/2392498

Katz, D., \& Kahn, R. L. (1978). The social psychology of organizations (2nd ed.). Wiley.

MacKenzie, S. B., \& Podsakoff, P. M. (2012). Common method bias in marketing: Causes, mechanisms, and procedural remedies. Journal of Retailing, 88(4), 542-555. https://doi.org/10.1016/j.jretai.2012.08.001

Michel, J. W. (2017). Antecedents of organizational citizenship behaviors: Examining the incremental validity of self-interest and prosocial motives. Journal of Leadership \& Organizational Studies, 24(3), 385-400. https://doi.org/10.1177/1548051816683895

Moorman, R. H., \& Blakely, G. L. (1995). Individualism-collectivism as an individual difference predictor of organizational citizenship behavior. Journal of Organizational Behavior, 16(2), 127-142. https://doi.org/10.1002/job.4030160204 
Nielsen, T. M., Bachrach, D. G., Sundstrom, E., \& Halfhill, T. R. (2012). Utility of OCB: Organizational citizenship behavior and group performance in a resource allocation framework. Journal of Management, 38(2), 668-694. https://doi.org/10.1177/0149206309356326

Nurhanni, N., \& Radikun, T. B. S. (2016). Tekanan sosial untuk menikah pada wanita lajang memperkuat hubungan tuntutan kerja dan burnout. Universitas Indonesia.

Organ, D. W. (2009). Organizational Citizenship Behavior: It's Construct Clean-Up Time. Human Performance, 10(2), 85-97. https://doi.org/10.1207/s15327043hup1002_2

Podsakoff, N. P., Whiting, S. W., Podsakoff, P. M., \& Blume, B. D. (2009). Individual- and organizationallevel consequences of organizational citizenship behaviors: A meta-analysis. Journal of Applied Psychology, 94(1), 122-141. https://doi.org/10.1037/a0013079

Pooja, A. A., De Clercq, D., \& Belausteguigoitia, I. (2016). Job stressors and organizational citizenship behavior: The roles of organizational commitment and social interaction. Human Resource Development Quarterly, 27(3), 373-405. https://doi.org/10.1002/hrdq.21258

Preacher, K. J., \& Hayes, A. F. (2008). Asymptotic and resampling strategies for assessing and comparing indirect effects in multiple mediator models. Behavior Research Methods, 40(3), 879-891. https://doi.org/10.3758/BRM.40.3.879

Purba, D. E., \& Muhammad, F. (2020). Job insecurity and organizational citizenship behavior: The role of affective commitment. Humanitas: Indonesian Psychological Journal, 17(2), 80-93. https://doi.org/10.26555/humanitas.v0i0.14916

Randolph, W. A. (1995). Navigating the journey to empowerment. Organizational Dynamics, 23(4), 1932. https://doi.org/10.1016/0090-2616(95)90014-4

Rizzo, J. R., House, R. J., \& Lirtzman, S. I. (1970). Role conflict and ambiguity in complex organizations. Administrative Science Quarterly, 15(2), 150-163. https://doi.org/10.2307/2391486

Schlechter, A. F., \& Engelbrecht, A. S. (2006). The relationship between transformational leadership, meaning, and organisational citizenship behaviour. Management Dynamics: Journal of the Southern African Institute for Management Scientists, 15(4), 1-15.

Seibert, S. E., Wang, G., \& Courtright, S. H. (2011). Antecedents and consequences of psychological and team empowerment in organizations: A meta-analytic review. Journal of Applied Psychology, 96(5), 981-1003. https://doi.org/10.1037/a0022676

Spreitzer, G. M. (1995). Psychological empowerment in the workplace: Dimensions, measurement, and validation. Academy of Management Journal, 38(5), 1442-1465. https://doi.org/10.2307/256865

Sulea, C., Virga, D., Maricutoiu, L. P., Schaufeli, W., Zaborila Dumitru, C., \& Sava, F. A. (2012). Work engagement as mediator between job characteristics and positive and negative extra-role behaviors. Career Development International, 17(3), 188-207. https://doi.org/10.1108/13620431211241054

Suresh, S., \& Venkatammal, P. (2010). An antecedents of organizational citizenship behavior. Journal of the Indian Academy of Applied Psychology, 36(2), 276-286.

Taylor, J. (2013). Goal setting in the Australian public service: Effects on psychological empowerment and organizational citizenship behavior. Public Administration Review, 73(3), 453-464. https://doi.org/10.1111/puar.12040 
Turnipseed, D. L., \& Rassuli, A. (2005). Performance perceptions of organizational citizenship behaviours at work: A bi-level study among managers and employees. British Journal of Management, 16(3), 231-244. https://doi.org/10.1111/j.1467-8551.2005.00456.x

Williams, L. J., \& Anderson, S. E. (1991). Job satisfaction and organizational commitment as predictors of organizational citizenship and in-role behaviors. Journal of Management, 17(3), 601-617. https://doi.org/10.1177/014920639101700305 